"Impact of macroeconomic factors and interaction with institutional performance on Vietnamese bank share prices"

\begin{tabular}{|c|c|}
\hline AUTHORS & Nguyen Phu Ha id https://orcid.org/0000-0003-0211-6229 \\
\hline ARTICLE INFO & $\begin{array}{l}\text { Nguyen Phu Ha (2021). Impact of macroeconomic factors and interaction with } \\
\text { institutional performance on Vietnamese bank share prices. Banks and Bank } \\
\text { Systems, 16(1), 127-137. doi:10.21511/bbs.16(1).2021.12 }\end{array}$ \\
\hline DOI & http://dx.doi.org/10.21511/bbs.16(1).2021.12 \\
\hline RELEASED ON & Monday, 22 March 2021 \\
\hline RECEIVED ON & Thursday, 04 February 2021 \\
\hline \multirow[t]{2}{*}{ ACCEPTED ON } & Monday, 15 March 2021 \\
\hline & $(\mathrm{cc}) \mathrm{EY}$ \\
\hline LICENSE & $\begin{array}{l}\text { This work is licensed under a Creative Commons Attribution } 4.0 \text { International } \\
\text { License }\end{array}$ \\
\hline JOURNAL & "Banks and Bank Systems" \\
\hline ISSN PRINT & $1816-7403$ \\
\hline ISSN ONLINE & $1991-7074$ \\
\hline PUBLISHER & LLC "Consulting Publishing Company "Business Perspectives" \\
\hline FOUNDER & LLC "Consulting Publishing Company "Business Perspectives" \\
\hline & $\begin{array}{l}\text { Z:- } \\
\text { =-:- }\end{array}$ \\
\hline NUMBER OF REFERENCES & NUMBER OF FIGURES \\
\hline 44 & 4 \\
\hline
\end{tabular}

(C) The author(s) 2023. This publication is an open access article. 


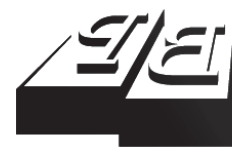

BUSINESS PERSPECTIVES

(O)

LLC "CPC "Business Perspectives"

Hryhorii Skovoroda lane, 10, Sumy, 40022, Ukraine

www.businessperspectives.org
Received on: $4^{\text {th }}$ of February, 2021 Accepted on: $15^{\text {th }}$ of March, 2021 Published on: $22^{\text {nd }}$ of March, 2021

(c) Nguyen Phu Ha, 2021

Nguyen Phu Ha, Ph.D., Chair of the Banking Department, Faculty of Finance and Banking, University of Economics and Business, Vietnam National University, Vietnam.

\section{IMPACT OF MACROECONOMIC FACTORS AND INTERACTION WITH INSTITUTIONAL PERFORMANCE ON VIETNAMESE BANK SHARE PRICES}

\begin{abstract}
Shares of listed banks in Vietnam gain a lot of interest from investors and regulators. It is important to study the primary drivers of the banks' share prices. In this context, Gross Domestic Product (GDP), Gold Price (GP), Ninety-day Interbank Interest Rate (R), and USD/VND Exchange Rate (FX) are selected as representatives for macroeconomic variables. A new contribution of this study is the application of interactive factors between macroeconomics and bank performance (i.e., Equity Capital (E), Deposit Amounts (D), Loan Amounts (L), Non-performing Loans (NPLs), Leverage (LEV), Capital Adequacy Ratio (CAR), Return on Assets (ROA), and Stock Beta (Beta)) in evaluating their impact on bank share prices. Applying the econometric method of Two-Stage Least Square (2SLS) and the quarterly financial data of 13 listed banks from Q1/2009 to Q3/2020, the regression results show that GDP improvements can foster an increase in bank share prices, and this impact is strengthened if banks have good performance of ROA, CAR, and with strict control of NPLs. The R also has a positive impact on bank share prices, and the price level increases if NPLs, LEV, and Beta are controlled at optimal levels. However, empirical evidence drawn from the study also suggests that an increase in FX and GP is not a significant contributor to bank share prices, especially if the bank does not manage NPLs and LEV. Moreover, the impact of $\mathrm{E}, \mathrm{D}$, and $\mathrm{L}$ on the movements of bank share prices is not significant.
\end{abstract}

\section{Keywords banks, share prices, macroeconomics, institutional performance}

JEL Classification G11, G12, G21, E02

\section{INTRODUCTION}

In the security market, news about share prices is published daily, and any change in market price levels can measure stock returns. From the perspectives of both investors and issuers, understanding a series of factors influencing share prices is vital to ensure that investment decisions or equity financing are made at the appropriate time and scale. For Vietnamese commercial banks, raising equity from the private sector, especially from the stock market, is an integral part of their financial strategy. The share prices are affected by a confluence of factors existing in the national economic environment and the creditworthiness of these banks.

Historically, Vietnamese commercial banks listed their shares on local stock exchanges later than firms in other industries. The first listed bank was ACB Bank in 2006, followed by Vietcombank and VietinBank in 2009. Among 30 domestic banks licensed by the State Bank of Vietnam (SBV) by December 2020, 10 banks are listed on the Ho Chi Minh Stock Exchange (HOSE), three are listed on the Hanoi Stock Exchange (HNX) and five are trading on the Unlisted Public 
Company Market (UPCOM). Although the number of the bank shares are few, they play a vital role because there are at least 10 Vietnamese banks included in the benchmark VN30 and HNX30 Indices ${ }^{1}$. The market capitalization of bank shares has increased from 26.39 percent in 2019 to 28.52 percent by the end of 2020. Decision number 242/QD-TTg dated February 28, 2019 of the Prime Minister approving the scheme for "Restructuring securities and insurance markets by 2020 and vision to 2025" indicates that all banks in Vietnam must issue stock on the local stock exchanges in order to increase transparency and the number of shares available for trading. This decision is considered a positive step forward for the continued development of the banking system.

From 2009 to 2020, the average adjusted closing price of bank stocks in Vietnam fluctuated dramatically from 3,460 VND to 90,200 VND per share. Prior research has addressed the "drivers" of banks' share price. For example, Ton (2007) explained that the downtrend of bank stocks during 2006-2007 was due to the inconsistency in strategic plans to raise funds from the stock market. Le (2010) concluded the reason for investors not to include bank shares into their investment portfolio was due to the unstable economic conditions, especially during and after the Global Finance Crisis 2007-2008. Meanwhile, domestic banks continue with additional equity issuance schemes to meet the capital adequacy of 3,000 billion VND under commitments with SBV. Nguyen (2017) investigated the impact of macroeconomic conditions on banks' share prices and found that inflation, exchange rate and money supply were the most important factors affecting bank share prices during 2006-2015. In addition, Vo (2015) posited that scale efficiency was an important factor to determine bank stock returns during 2006-2012.

Determinants of security price behavior can be found in the Dividend Discount Model (Miller \& Modigliani, 1961), the Efficient Market Hypothesis (Fama, 1970), and the Arbitrage Pricing Theory (Ross, 1976). Along with the above traditional theories, the dynamic relationship among macroeconomic indicators and share prices are also illustrated in a number of research studies by Fama and French (1989), Jensen and Johnson (1995), King and Watson (1996), and Miskin (2001). Furthermore, macroeconomic and institutional factors affecting bank share prices are also included (Ali et al., 2018; Banerjee et al., 2017; Bhattarai, 2016; Al-Shubiri, 2010; Angello \& Sousa, 2014; Narayan et al., 2015). The purpose of this study is to address two important issues:

- First, evaluating the level of interactive impact of macroeconomic climate and institutional characteristics of banks on the behavior of bank share prices.

- Second, providing insights for bank regulators, policy makers, and investors in order to assist their understanding of the factors influencing share prices.

\section{LITERATURE REVIEW}

The connection between macroeconomic factors and financial asset prices are explained by financial economic theories. According to Keynes (1937), changes in money supply caused changes in the quantity of loanable funds through the banking system, resulting in changes in market interest rates. The Dividend Discount Model developed by Miller and Modigliani (1961) states that the current share price is the sum of expected future cash flow payments; and these are discounted back to present values at an appropriate rate of return and are affected by national economic conditions.

Fama (1970) postulated that security prices in efficient capital markets "fully" reflected available information. There are three primary forms of price adjustments:

1) the weak form is associated with historical data of stock prices;

2) the semi-strong form is associated with cur-

1 The VN30 and HNX30 track the performance of the 30 largest stocks on HOSE and HNX by market capitalization and trading liquidity. 
rent and available information in the public sphere; and

3) the strong form is associated with undisclosed information (non-public) available to powerful investors or business groups.

The Arbitrage Pricing Theory (APT) proposed by Ross (1976) states the prediction of stock returns is based on the estimation of the sensitivity of the stock price combined with systematic factors such as interest rates and foreign exchange rates.

Sharpe (1964) developed the Capital Asset Pricing Model (CAPM) and pointed out that the risk-free interest rate, risk bearing interest rates and beta coefficients of the portfolio were the three main drivers for stock prices. Along with the basic CAPM approach, the international CAPM developed by Stulz (1999) highlighted the inclusion of exchange rate in the stock price model. Dornbusch and Fischer (1986) concluded that an appreciation of the domestic currency would produce a positive effect on stock prices of the import-dependent country by reducing costs of production in most business industries and create a negative effect on the domestic stock market for an export-dependent country.

In association with financial economic theories, empirical evidence about the impact of the macroeconomic environment on the behavior of share prices was found (Mishra et al., 2020; J. Khan \& I. Khan, 2018; Hsing \& Hsieh, 2012). While Phan et al. (2015) focused more on the effect of business cycle on share prices, Kurov and Gu (2016) and Chen et al. (2013) studied the effects of the business cycle in both bull and bear market conditions. In addition, the statistically significant and positive link between real GDP and share prices is identified in a number of empirical studies (Shula, 2017; Moore \& Wang, 2014; Hsing et al., 2012).

Conclusions about the interactions between market interest rates and share prices are documented in a number of studies, however the directional relationship varied according to each specific case. Montes and Tiberto (2012), Osamwonyi and Evbayiro-Osagie (2012) argued that the short-term interest rate was considered as the opportunity cost for investing money, so it was negatively related to the share price, whereas Horobet and Dumitrescu (2009) suggested a positive relationship.

The link between exchange rates and share prices or between gold prices and share prices is also widely investigated. Garg and Kalra (2018), Luthra and Mahajan (2014) identified a positive relationship, whereas Montes and Tiberto (2012), Ewing and Thompson (2007) confirmed a negative relationship. Baur and Lucey (2010) and Chinzara (2011) found empirical evidence about the positive correlation between gold price and the stock price. However, Singhal et al. (2019) and Garefalakis et al. (2011) argued that gold price was inversely related to share prices as gold was the best alternative for share prices.

Regarding the long-term determinants of bank share prices in emerging markets, Narayan and Bannigidadmath (2015) examined causality effect of macroeconomic variables on bank share prices in the Indian security market during 2008 and 2018. Regression results from the combination of a Panel Granger Causality Test with the data of 13 listed commercial banks suggested interest rates had a negative effect on share price, whereas industrial production and the real exchange rates had a positive effect in the long run.

Banerjee et al. (2017) applied monthly data using money supply, interest rates and cash remittances, and share prices of listed banks on the Dhaka Stock Exchange from June 2012 to December 2015. Using panel data analysis and cointegration tests with dynamic OLS, regression results confirmed the most important factors affecting bank share prices are money supply, interest rates and cash remittances. The study also suggested a negative association between lending interest rates and share prices.

Ali et al. (2018) used monthly panel data of 8 major banks in Pakistan from January 2005 to December 2013. The findings revealed that the market index has a positive effect, whereas the exchange rates and short-term interest rates have negative effect on the bank share price. Arshad et al. (2015) focused on factors affecting share prices of 22 commercial banks listed on the Karachi stock exchange between 2007 and 2013. The findings confirmed that short-term interest rates had a negative relationship with bank share prices. 
According to Naveed and Ramzan (2013), the share price of 15 listed banks on the Karachi Stock Exchange were affected by bank characteristics such as bank size and profitability. Al-Shubiri (2010) applied a panel data of 14 commercial banks listed on the Amman Stock Exchange from June 2010 to December 2015. Conclusions from this study confirmed the link between the share price and macroeconomic factors, in which money supply, exchange rate change, and interest rates not only reflect the long-run relationship but also produced positive effects on the bank share prices, whereas real GDP and inflation were found to have negative effects on bank share prices.

According to Almumani (2014), bank share prices are positively influenced by bank-specific factors and distribution of net income such as EPS, P/E and DPS. Furthermore, Bhattarai (2016) examined the determinants of share prices of commercial banks listed on the Nepal security market between 2006 and 2014. Findings from the study suggest EPS and P/E multiples had a statistically significant and positive effect on the share prices of Nepalese commercial banks.

\section{METHODOLOGY}

The data applied in this study is secondary data provided by FiinPro and General Statistics Office of Vietnam, and the selection of variables is based on the quarter period covering a period from Q1/2009 to Q3/2020. Variables investigated include macroeconomic indicators, the average bank share price at the close of each trading day on HOSE and HNX, and indicators abstracted from the financial statements of 13 listed banks. The exact variables used in the study are listed in Table 1. Except for LEV, Beta and ROA, natural logarithm transformation for other variables is applied with the aim to make the data more symmetric. Two-Stage Least Squares (2SLS) approach is applied to evaluate the impact of macroeconomics and interactive factors between macroeconomics and institutional performance on the bank share prices.

First, the general model using quarterly panel data is suggested as follows:

$$
\operatorname{LnSP} P_{i t}=\beta^{\prime} X_{i t}+\beta^{\prime \prime} L_{i t}+u_{i t}
$$

where $\operatorname{LnSP} P_{i t}$ is the natural logarithm of adjusted closing share price of bank $i$ at quarter $t ; X_{i t}$ is the matrix of macroeconomic variables proposed in Table 1, which represent independent variables; $L_{i t}$ is the matrix of interactive variables; and $u_{i t}$ is error term.

Table 1. Variables used in the study

\begin{tabular}{|c|c|}
\hline Variables & Details \\
\hline \multicolumn{2}{|r|}{ Dependent variable } \\
\hline $\operatorname{LnSP} P_{i}$ & $\begin{array}{l}\text { The adjusted closing price; } S P_{i t} \text { means price of listed } \\
\text { bank } i \text { collected at the end of quarter } t\end{array}$ \\
\hline \multicolumn{2}{|r|}{ Independent variables } \\
\hline \multicolumn{2}{|r|}{ Macro-economic variables } \\
\hline $\mathrm{GDP}_{\mathrm{t}}$ & $\begin{array}{l}\text { The gross domestic products; } G D P_{t} \text { means the GDP } \\
\text { amount of Vietnam at the end of quarter } t\end{array}$ \\
\hline $\mathrm{GP}_{\mathrm{t}}$ & $\begin{array}{l}\text { The average selling price of gold per ounce in retail } \\
\text { markets; GP means GP at the end of quarter } t\end{array}$ \\
\hline$F X_{t}$ & $\begin{array}{l}\text { The inter-bank exchange rate between the United } \\
\text { States Dollar and Vietnam Dong; } F X_{t} \text { means } F X \text { at } \\
\text { the end of quarter } t\end{array}$ \\
\hline $\mathrm{R}_{\mathrm{t}}$ & $\begin{array}{l}\text { The 90-day interest rate in Vietnam interbank } \\
\text { market, } R_{t} \text { means } R \text { at the end of quarter } t\end{array}$ \\
\hline \multicolumn{2}{|c|}{ Bank characteristics and performance indicators } \\
\hline$E_{i, t}$ & $\begin{array}{l}\text { The equity capital number of a bank; } E_{i t} \text { means } E \text { of } \\
\text { the listed bank } i \text { at the end of quarter } t\end{array}$ \\
\hline$D_{i, t}$ & $\begin{array}{l}\text { The deposit amounts of a bank; } D_{i t} \text { means } D \text { of the } \\
\text { listed bank } i \text { at the end of quarter } t\end{array}$ \\
\hline $\mathrm{L}_{\mathrm{it}}$ & $\begin{array}{l}\text { The lending amounts of a bank; } L_{i t} \text { means } L \text { of the } \\
\text { listed bank } i \text { at the end of quarter } t\end{array}$ \\
\hline$N P L_{i t}$ & $\begin{array}{l}\text { The non-performing loans of a bank, } N P L_{i t} \text { means } \\
N P L \text { of the listed bank } i \text { at the end of quarter } t\end{array}$ \\
\hline $\mathrm{ROA}_{\text {it }}$ & $\begin{array}{l}\text { The return on assets of a bank; } R O A_{i t} \text { means } R O A \text { of } \\
\text { listed bank } i \text { at the end of quarter } t\end{array}$ \\
\hline Beta $_{\text {it }}$ & $\begin{array}{l}\text { The volatility of share of a bank compared to the } \\
\text { systematic risk of the entire market; } \text { Beta }_{i t} \text { means } \\
\text { beta of listed bank } i \text { at the end of quarter } t\end{array}$ \\
\hline LEV $_{\text {it }}$ & $\begin{array}{l}\text { The proportion of debt to a bank's equity; } L E V_{i t} \\
\text { means } L E V \text { of listed bank } i \text { at the end of quarter } t\end{array}$ \\
\hline $\mathrm{CAR}_{\text {it }}$ & $\begin{array}{l}\text { The ratio of a bank equity capital to the risk } \\
\text { weighted assets; } C A R_{i t} \text { applied to listed bank } i \text { at } \\
\text { period } t\end{array}$ \\
\hline
\end{tabular}

Based on 2SLS, the OLS estimator $\alpha_{H}$ and the fitted values $\widehat{X_{k, j}}$ are specified as:

$X_{k, j}=\alpha_{1} Z_{1, j}+\alpha_{2} Z_{2, j}+\ldots+\alpha_{H} Z_{H, j}+v_{j}$.

Then, the dependent variable $\operatorname{LnSP}$ on the fitted values $X_{k, j}$ is specified as:

$\widehat{X_{k, j}}=\widehat{\alpha_{1}} Z_{1, j}+\widehat{\alpha_{2}} Z_{2, j}+\ldots+\widehat{\alpha_{H}} Z_{H, j}$.

The next step is to regress $L n S P$ on the fitted values $X_{k, j}$, where 


$$
\begin{aligned}
& \widehat{\operatorname{LnSP_{k,j}}}=\widehat{\beta_{1} X_{k, j}}+\widehat{\beta_{1} X_{2, j}}+\ldots \\
& +\widehat{\beta_{K} X_{k, j}}+\varepsilon_{j} .
\end{aligned}
$$

The 2SLS estimator $\widehat{\beta_{2 S L S}}$ corresponds to the OLS estimator is, then, computed. Finally, Sargan and Wu-Hausman tests are applied to identify weak instrument and endogeneity issues.

To investigate the effects of macroeconomics factors and bank performance on bank share prices, four separate econometric models using different combination of interactive variables are specified, in which each of the four key macro-economic variables (i.e., $G D P, R, F X$ and $G P$ ) is interacted with the other variables of institutional performance of banks (see Table 2).

\section{RESULTS}

The descriptive statistics found in Table 2 indicate that no selected variable is in violation with the condition of collinearity (i.e., VIF value must be lower than 10). Specifically, three variables, including $G D P \cdot E, G D P \cdot D$, and $G D P \cdot L$, are removed in Model 1 because of their violation of VIF condition. Similarly, five variables, including $R, R \cdot E, R \cdot D$, $R \cdot L, R \cdot R O A$, are removed in Model 2. Three variables, including $F X \cdot E, F X \cdot L$, and $F X \cdot C A R$, are eliminated in Model 3, while four variables, including $G P \cdot E, G P \cdot D, G P \cdot L$, and $G P \cdot C A R$, are eliminated in Model 4.

The total observations for LnSP are 423 because each bank had different listing times, while those for determinants of bank share prices are 611, ensuring no value is missed during 47 quarters from Q1/2009 to Q3/2020. The average bank share price is $13,586 \mathrm{VND}$ (equal to $\operatorname{LnSP}=9.515$ ) associated with a range from $3,465 \mathrm{VND}$ to $90,415 \mathrm{VND}$ $(\operatorname{LnSP}=8.149$ to 11.410$)$. For the four key macroeconomic variables, the average GDP is reported at 6,539 thousand billion VND and $R$ is equal to $1.962 \%$. Besides, $F X$ in the study period is 9.97 while GP is 17.042 in terms of natural logarithm. Furthermore, details about standard deviation, ranges of determinant variables are shown in Table 2.

\begin{tabular}{|c|c|c|c|c|c|c|}
\hline Variables & Variables used in the model & Obs. & Mean & Std. dev. & Min & Max \\
\hline LnSP & Models 1, 2, 3, \& 4 & 423 & 9.515 & 0.578 & 8.149 & 11.410 \\
\hline GDP & Models 2, 3, \& 4 & 611 & 6.539 & 0.651 & 5.149 & 8.336 \\
\hline $\mathrm{R}$ & Models 1, 3, \& 4 & 611 & 1.962 & 0.468 & 0.507 & 2.738 \\
\hline FX & Models 1, 2 \& 4 & 611 & 9.971 & 0.077 & 9.782 & 10.074 \\
\hline GP & Models 1, 2, \& 3 & 611 & 17.402 & 0.201 & 18.809 & 17.833 \\
\hline GDP.NPL & \multirow{4}{*}{ Model 1} & 611 & 33.264 & 23.845 & 0.342 & 79.765 \\
\hline GDP.CAR & & 611 & 0.016 & 0.031 & -0.092 & 0.218 \\
\hline GDP.ROA & & 611 & 0.339 & 0.286 & 0.125 & 1.326 \\
\hline GDP.Beta & & 611 & 4.265 & 4.882 & -6.637 & 28.982 \\
\hline $\mathrm{R} \cdot \mathrm{NPL}$ & \multirow{4}{*}{ Model 2} & 611 & 9.112 & 6.803 & 0.023 & 21.960 \\
\hline $\mathrm{R} \cdot$ Beta & & 611 & 1.101 & 1.308 & -1.964 & 7.889 \\
\hline$R \cdot L E V$ & & 611 & 16.219 & 13.596 & 0.065 & 52.831 \\
\hline$R \cdot C A R$ & & 611 & 0.005 & 0.009 & -0.034 & 0.058 \\
\hline FX.LEV & \multirow{5}{*}{ Model 3} & 611 & 87.050 & 67.704 & 0.023 & 235.982 \\
\hline $\mathrm{FX} \cdot \mathrm{NPL}$ & & 611 & 49.480 & 34.520 & 0.011 & 96.262 \\
\hline FX·Beta & & 611 & 6.227 & 6.984 & -9.473 & 40.662 \\
\hline FX'ROA & & 611 & 0.516 & 0.438 & 0.013 & 2.110 \\
\hline FX.D & & 611 & 19.942 & 0.153 & 19.565 & 20.148 \\
\hline GP.LEV & \multirow{4}{*}{ Model 4} & 611 & 156.599 & 120.254 & 0.078 & 407.952 \\
\hline GP.NPL & & 611 & 89.318 & 62.186 & 0.012 & 172.848 \\
\hline GP.Beta & & 611 & 11.022 & 12.143 & -15.800 & 66.510 \\
\hline $\mathrm{GP} \cdot \mathrm{ROA}$ & & 611 & 0.942 & 0.812 & 0.012 & 4.085 \\
\hline
\end{tabular}

Table 2. Descriptive statistics for variables used in the study 
Correlation among variables applied in the four models is illustrated in Table 3. The correlation between $L n S P$ and GDP is shown positively at 0.474 , whereas those between $F X ; R$ and $G P$ are shown negatively at $-0.363,-0.379$ and -0.445 , respectively. In Model $1, \operatorname{LnSP}$ is positively correlated with three interactive variables, which include GDP.NPL, GDP.CAR and GDP.Beta, and the correlation is in the range from 0.337 to 0.731. In Model 2, correlation between LnSP and other interactive variables is weak, which ranges from -0.206 to 0.345 . In Model 3, correlation between $L n S P$ and $F X \cdot N P L$, and $L n S P$ and $F X \cdot D$ is moderate at 0.414 and -0.366 respectively. In Model 4, correlation coefficients between LnSP and other interactive variables are weak and range from -0.202 to 0.250 .

The regression results are presented in Table 4. In Model $1, \operatorname{LnSP}$ is affected by a set of factors, which include $R, F X, G P, G D P \cdot N P L, G D P \cdot C A R$, and GDP.ROA. The regression coefficients of $R, G D P \cdot C A R, G D P \cdot R O A$ and GDP.NPL are positive and significant at 1.753, 2.014, 1.827 and 0.016 , while those of $F X$ and $G P$ are negative and significant at -2.038 and -0.270 . In Model 2, $F X$ and $G P$ also show negative and significant effects on LnSP, and the regression coefficients show larger absolute levels at 6.807 and 1.452, respectively. Then, $R \cdot N P L, R \cdot B e t a$, and $R \cdot L E V$ have negative and significant effects on LnSP; and the coefficients range from -0.214 to -0.022 .

Meanwhile, $R \cdot C A R$ has a significant and positive relationship with $L n S P$. In Model 3, GDP and $R$ are significantly positive with $L n S P$, and regression coefficients are equal to 1.941 and 0.528 . Besides, $F X \cdot N P L$ also has a positive and significant relationship with $\operatorname{LnSP}$, and it is equivalent to 0.037 . However, results show that GP, FX.LEV,

Table 3. Correlations among variables used in the models

\begin{tabular}{|c|c|c|c|c|c|c|c|c|c|}
\hline \multicolumn{10}{|c|}{ Models (1) (2) (3) (4) } \\
\hline Variables & LnSP & GDP & $\mathbf{R}$ & FX & GP & \multicolumn{4}{|c|}{-} \\
\hline LnSP & 1.000 & - & - & - & - & \multicolumn{4}{|c|}{-} \\
\hline GDP & 0.474 & 1.000 & - & - & - & \multicolumn{4}{|c|}{-} \\
\hline$R$ & -0.370 & -0.610 & 1.000 & - & - & \multicolumn{4}{|c|}{-} \\
\hline $\mathrm{FX}$ & -0.363 & 0.730 & -0.580 & 1.000 & - & \multicolumn{4}{|c|}{-} \\
\hline GP & -0.440 & -0.631 & 0.462 & -0.520 & 1.000 & \multicolumn{4}{|c|}{-} \\
\hline \multicolumn{10}{|c|}{ Model 1} \\
\hline Variables & LnSP & GDP & $\mathbf{R}$ & FX & GP & GDP.NPL & GDP.CAR & GDP.ROA & GDP.Beta \\
\hline GDP.NPL & 0.531 & 0.695 & -0.513 & 0.690 & -0.465 & 1.000 & - & - & - \\
\hline GDP.CAR & 0.343 & 0.204 & 0.115 & 0.139 & -0.152 & 0.099 & 1.000 & - & - \\
\hline GDP.ROA & -0.023 & -0.248 & 0.356 & -0.202 & 0.074 & -0.292 & 0.413 & 1.000 & - \\
\hline GDP.Beta & 0.337 & 0.458 & -0.315 & 0.561 & -0.462 & 0.589 & 0.094 & -0.169 & 1.000 \\
\hline \multicolumn{10}{|c|}{ Model 2} \\
\hline Variables & $\operatorname{LnSP}$ & GDP & & FX & GP & $R \cdot N P L$ & R.Beta & R.LEV & $R \cdot C A R$ \\
\hline$R \cdot N P L$ & -0.102 & -0.392 & - & -0.231 & 0.297 & 1.000 & - & - & - \\
\hline $\mathrm{R} \cdot$ Beta & 0.131 & 0.139 & - & 0.363 & -0.241 & 0.371 & 1.000 & - & - \\
\hline$R \cdot L E V$ & -0.206 & -0.213 & - & -0.222 & 0.089 & 0.604 & 0.279 & 1.000 & - \\
\hline$R \cdot C A R$ & 0.345 & 0.207 & - & 0.144 & -0.158 & 0.124 & 0.116 & -0.072 & 1.000 \\
\hline \multicolumn{10}{|c|}{ Model 3} \\
\hline Variables & $\operatorname{LnSP}$ & GDP & $\mathbf{R}$ & FX & FX.LEV & FX'NPL & FX.Beta & FX'ROA & FX.D \\
\hline FX.LEV & 0.036 & 0.209 & -0.042 & 0.197 & 1.000 & - & - & - & - \\
\hline$F X \cdot N P L$ & 0.414 & 0.327 & -0.335 & 0.505 & 0.197 & 1.000 & - & - & - \\
\hline FX.Beta & 0.285 & 0.348 & -0.262 & 0.512 & 0.505 & 0.307 & 1.000 & - & - \\
\hline$F X \cdot R O A$ & -0.139 & -0.431 & 0.424 & -0.337 & 0.512 & 0.274 & 0.503 & 1.000 & - \\
\hline$F X \cdot D$ & -0.366 & 0.733 & -0.584 & 0.896 & -0.337 & -0.679 & -0.291 & -0.217 & 1.000 \\
\hline \multicolumn{10}{|c|}{ Model 4} \\
\hline Variables & LnSP & GDP & $\mathbf{R}$ & FX & GP & GP.LEV & GP.NPL & GP.Beta & GP.ROA \\
\hline GP.LEV & -0.059 & 0.071 & 0.071 & 0.073 & -0.068 & 1.000 & - & - & - \\
\hline GP.NPL & 0.230 & 0.049 & -0.136 & 0.272 & 0.176 & 0.227 & 1.000 & - & - \\
\hline GP.Beta & 0.250 & 0.295 & -0.228 & 0.482 & -0.308 & 0.178 & 0.374 & 1.000 & - \\
\hline GP.ROA & -0.202 & -0.519 & 0.477 & -0.416 & 0.371 & -0.638 & -0.165 & -0.249 & 1.000 \\
\hline
\end{tabular}


Table 4. Effects of macroeconomics and bank performance on bank share prices

\begin{tabular}{|c|c|c|c|c|c|c|c|c|}
\hline \multirow{2}{*}{ Variables } & \multicolumn{2}{|c|}{ Model (1) } & \multicolumn{2}{|c|}{ Model (2) } & \multicolumn{2}{|c|}{ Model (3) } & \multicolumn{2}{|c|}{ Model (4) } \\
\hline & Coef. & P-value & Coef. & P-value & Coef. & P-value & Coef. & P-value \\
\hline cons & 221.12 & 0.000 & 694.85 & 0.043 & 270.21 & 0.032 & 26.18 & 0.495 \\
\hline$G D P$ & - & - & 2.945 & 0.203 & $1.941 * *$ & 0.020 & $1.155^{* * *}$ & 0.001 \\
\hline$R$ & $1.753^{* * *}$ & 0.000 & - & - & $0.528^{*}$ & 0.060 & $1.246^{* * *}$ & 0.000 \\
\hline$F X$ & $-2.038^{* * *}$ & 0.000 & $-6.807^{*}$ & 0.053 & - & - & -2.713 & 0.056 \\
\hline$G P$ & $-0.270 * * *$ & 0.003 & $-1.452 * *$ & 0.015 & $-0.282^{*}$ & 0.086 & - & - \\
\hline$G D P \cdot N P L$ & $0.016^{* *}$ & 0.045 & - & - & - & - & - & - \\
\hline GDP.CAR & $2.014^{* * *}$ & 0.000 & - & - & - & - & - & - \\
\hline$G D P \cdot R O A$ & $1.827^{* * *}$ & 0.002 & - & - & - & - & - & - \\
\hline GDP.Beta & 0.004 & 0.735 & - & - & - & - & - & - \\
\hline$R \cdot N P L$ & - & - & $-0.214^{* * *}$ & 0.001 & - & - & - & - \\
\hline$R \cdot$ Beta & - & - & $-0.217^{*}$ & 0.057 & - & - & - & - \\
\hline$R \cdot L E V$ & - & - & $-0.022^{*}$ & 0.092 & - & - & - & - \\
\hline$R \cdot C A R$ & - & - & $2.654^{*}$ & 0.100 & - & - & - & - \\
\hline$F X \cdot L E V$ & - & - & - & - & $-0.007^{* *}$ & 0.019 & - & - \\
\hline$F X \cdot N P L$ & - & - & - & - & $0.037 * *$ & 0.000 & - & - \\
\hline FX.Beta & - & - & - & - & -0.007 & 0.388 & - & - \\
\hline$F X \cdot R O A$ & - & - & - & - & -0.302 & 0.525 & - & - \\
\hline$F X \cdot D$ & - & - & - & - & $-1.390 * *$ & 0.038 & - & - \\
\hline GP.LEV & - & - & - & - & - & - & $-0.004 * * *$ & 0.001 \\
\hline$G P \cdot N P L$ & - & - & - & - & - & - & $-0.013^{* * *}$ & 0.000 \\
\hline GP.Beta & - & - & - & - & - & - & 0.007 & 0.834 \\
\hline$G P \cdot R O A$ & - & - & - & - & - & - & $0.307^{*}$ & 0.098 \\
\hline $\begin{array}{l}\text { First stage } \\
\text { regression } \\
\text { statistics }\end{array}$ & \multicolumn{2}{|c|}{$\begin{aligned} \text { Adj. } R-s q & =0.4532 \\
\text { Prob }>F & =0.033\end{aligned}$} & \multicolumn{2}{|c|}{$\begin{aligned} \text { Adj. } R-s q & =0.3313 \\
\text { Prob }>F & =0.065\end{aligned}$} & \multicolumn{2}{|c|}{$\begin{aligned} \text { Adj. } R-s q & =0.2873 \\
\text { Prob }>F & =0.091\end{aligned}$} & \multicolumn{2}{|c|}{$\begin{array}{c}\text { Adj. } R-s q=0.4142 \\
\text { Prob }>F=0.1125\end{array}$} \\
\hline $\begin{array}{l}\text { Sargan test of } \\
\text { weak instrument }\end{array}$ & \multicolumn{2}{|c|}{$\begin{array}{l}\text { Chi2 }(7)=121.75 \\
\text { Prob }>\text { chi2 }=0.323\end{array}$} & \multicolumn{2}{|c|}{$\begin{array}{c}\text { Chi } 2(8)=128.15 \\
\text { Prob }>\text { chi } 2=0.334\end{array}$} & \multicolumn{2}{|c|}{$\begin{array}{c}\text { Chi2 }(8)=134.16 \\
\text { Prob }>\text { chi2 }=0.197\end{array}$} & \multicolumn{2}{|c|}{$\begin{array}{c}\text { Chi2 }(8)=106.11 \\
\text { Prob }>\text { chi2 }=0.446\end{array}$} \\
\hline $\begin{array}{l}\text { Wu-Hausman } \\
\text { test of } \\
\text { endogeneity }\end{array}$ & \multicolumn{2}{|c|}{$\begin{array}{c}\text { Dubin(score) } \operatorname{chi} 2(7)=82.17 \\
P<0.0000) \\
\text { Wu-Hausman } F(7,365)=14.38 \\
(p<0.0000)\end{array}$} & \multicolumn{2}{|c|}{$\begin{array}{c}\text { Dubin(score) chi } 2(8)= \\
104.86 \\
P<0.0000) \\
\text { Wu-Hausman F(7,326) } \\
=20.68 \\
\quad(p<0.0000)\end{array}$} & \multicolumn{2}{|c|}{$\begin{array}{c}\text { Dubin(score) chi2 }(8)= \\
80.84 \\
P<0.0000) \\
\text { Wu-Hausman } F(8,287)= \\
12.99 \\
(p<0.0000\end{array}$} & \multicolumn{2}{|c|}{$\begin{array}{c}\text { Dubin(score) chi2 }(7)=58.31 \\
P<0.0000) \\
\text { Wu-Hausman } F(7.365)= \\
9.452(p<0.0000)\end{array}$} \\
\hline
\end{tabular}

Note: ${ }^{* *}$ P-value is less than 0.01 (P-value $\left.<0.01\right) ;{ }^{* *}$-value $<0.05 ;{ }^{*}$ P-value $<0.1$.

and $F X \cdot D$ have a negative impact on $\operatorname{LnSP}$, and regression coefficients equal $-0.282,-0.007$ and -1.390 , respectively. In Model 4, GDP and $R$ also have a significantly positive impact on $L n S P$, and the coefficients equal 1.155 and 1.246 , respectively. $G P \cdot R O A$ also shows a positive impact on $\operatorname{LnSP}$, with the coefficient equivalent to 0.307 , whereas $G P \cdot L E V, G P \cdot N P L$ show significantly negative impacts on $L n S P$, and coefficients equal -0.004 and -0.013 . respectively.

Wu-Hausman tests are conducted to examine whether or not an endogenous problem exists in the four models. If the P-values in the four models were lower than $5 \%$, then the null hypothesis
(Ho) is rejected; indicating the existence of endogeneity. As for results of Sargan tests, P-values in the four models are higher than 5\%, implying that the instrumental variables used in the regressions satisfied the required conditions of instrumental variables applied in 2SLS.

Considering the impact of $G D P$ on $L n S P$, it was found that the GDP variable is positively interacted with bank share prices, and the regression coefficients range from 1.153 to 1.941 , indicating that $L n S P$ would increase from 1,153 to 1,941 VND if GDP increases one thousand billion VND. When GDP is interacted with $C A R$, the impact is stronger and the regression coefficient is equal to 2.014 (see Model 1). 
The impact of $R$ on $\operatorname{LnSP}$ suggests a positive impact on bank share prices, and regression coefficients are in a range from 0.528 to 1.246 , implying that LnSP tends to increase from 528 VND to 1,246 VND if $R$ increases by $1 \%$. The impact is more pronounced if interest rate is interacted with $C A R$, leading to higher impact level at 2,564 VND.

The impact of $F X$ on LnSP suggests that USD/ VND exchange rates negatively affect bank share prices, and coefficients range from -6.807 to -2.038 , meaning that a 1,000 VND increase of USD price in relation to VND might lead to a decrease in bank share prices from $-2.038 \mathrm{VND}$ to -6.807 VND. When $F X$ is interacted with $D$, the impact is also negative, but the level of impact is smaller and regression coefficients range from -1.301 to -0.007 .

Finally, the impact of retail gold price on bank share prices also suggests a negative trend. If $G P$ levels are reduced by 1 million VND, LnSP tends to increase by $270 \mathrm{VND}$ to $1,452 \mathrm{VND}$. If $G P$ interacts with either $L E V$ or $R O A$, the regression results are negative.

\section{CONCLUSION}

During the period from Q1/2006 to Q3/2020, the share price of 13 listed banks in Vietnam responded sensitively to macroeconomic conditions. Sustainable improvement of GDP can support the rise in bank share prices. This impact is weakened or strengthened, depending on how GDP was interacted with characteristics and performance of these banks. As far as positive impact of GDP is concerned, the rise in GDP in association with the rise in ROA, or the rise in GDP in association with CAR would strengthen the positive effect, whereas the rise in GDP in association with NPLs would weaken the positive effect. Specifically, the regression coefficients ranged from 1.153 to1.941 would decrease to 0.016 .

Ninety-day interbank interest rate was found to be a key driver for bank share prices. Findings from the study confirmed that a rise in 90-day interbank interest rate leads to a rise in the bank share prices, suggesting higher expectations of investors about returns from bank shares. In association with a good plan to increase the capital adequacy, the impact would be stronger, otherwise, weaker if an increase in interest rate is combined with an increase in non-performing loans, escalating financial leverage and increasing systematic risk of bank shares.

The negative impact of USD/VND exchange rate and the bank share prices in the long run shown in the study suggest that the depreciation of the U.S. currency in the Vietnamese market would result in the fall of bank share price.

The depreciation in retail price of gold would result in a decrease in bank share prices, although statistical significance was not found by its interaction with bank characteristics and performance. This finding is consistent with findings found in the studies of Singhal et al. (2019), Garefalakis et al. (2011) implying that gold is an alternative investment for stocks. Except for capital adequacy, beta, leverage and non-performing loans, evidence about the impact of equity capital, deposit and lending was not found to be statistically significant in this study.

Second, the main goal of this study for determinants of bank share prices in Vietnam did provide a strong empirical basis for decision making by policy makers, regulators and investors. For listed banks, a successful plan to raise equity from the stock market is relevant to the sustainable growth of equity value after fund raising, coinciding with a strong growth of bank share prices in the future. In this regard, taking market interest rates, USD/VND exchange rate and the gold market into consideration and controlling for non-performing loans and the capital adequacy, as well as an appropriate level of financial leverage, are required steps in preparation for equity financing plans. For investors, improving knowledge and skills on analysis of macroeconomic conditions and the bank financial statements, as well as market information, is very important for making accurate decisions. Finally, the State Bank of 
Vietnam should maintain a stable macroeconomic and monetary environment with a flexible monetary policy. For example, adjustments leading to the inappropriate level of basic interest rates, or intervention to raise USD/VND exchange rates and gold prices can negatively affect bank stock prices.

\section{AUTHOR CONTRIBUTIONS}

Conceptualization: Nguyen Phu Ha.

Data curation: Nguyen Phu Ha.

Formal analysis: Nguyen Phu Ha.

Investigation: Nguyen Phu Ha.

Methodology: Nguyen Phu Ha.

Resources: Nguyen Phu Ha.

Supervision: Nguyen Phu Ha.

Validation: Nguyen Phu Ha.

Visualization: Nguyen Phu Ha.

Writing - original draft: Nguyen Phu Ha.

\section{REFERENCES}

1. Ali, S., Bashir, T., Ahmed, T., Ishaq, A., \& Shahzad, S. J. H. (2018). The Determinants of Bank Stock Prices: A Panel Approach. South Asian Journal of Management Sciences, 12(2), 116-129. https://doi.org/10.21621/ sajms.2018122.01

2. Al-Shubiri, F. N. (2010). Capital structure and value firm: an empirical analysis of abnormal returns. Economia. Seria Management, 13(2), 240-252. Retrieved from http://www. management.ase.ro/reveconomia/2010-2/3.pdf

3. Alumani, M. A. (2014) Determinants of equity share prices of the listed banks in Amman stock exchange: Quantitative approach. International Journal of Business and Social Science, 5(1), 91-104. Retrieved from https://ijbssnet. com/journals/Vol_5_No_1_January_2014/12.pdf

4. Angello, L., \& Sousa, R. M. (2014). The determinants of the volatility of fiscal policy discretion. Fiscal Studies, 35(1), 91-95. https://doi.org/10.1111/j.14755890.2014.12024.x

5. Arshad, Z., Arshaad, A. R., Yousaf, S., \& Jamil, S. (2015). Determinants of share prices of listed commercial banks in Pakistan. IOSR Journal of Economics and Finance, 6(2), 5664. Retrieved from http://www. iosrjournals.org/iosr-jef/papers/ Vol6-Issue2/Version-3/I06235664. pdf

6. Banerjee, P. K., Ahmed, M. N., \& Hossain, M. M. (2017). Bank, Stock Market and Economic Growth: Bangladesh Perspective. The Journal of Developing Areas, 51(2), 17-29. https://doi. org/10.1353/jda.2017.0028

7. Baur, D. G., \& Lucey, B. M. (2010). Is gold a hedge or a safe haven? An analysis of stocks, bonds and gold. Financial Review, 45(2), 217-229. https://doi.org/10.1111/ j.1540-6288.2010.00244.x

8. Bhattarai, Y. R. (2016). Determinants of Share Price of Nepalese Commercial Banks. Economic Journal of Development Issues, 17(1-2), 187-198. https:// doi.org/10.3126/ejdi.v17i12.14528

9. Chen, L., Da, Z., \& Zhao, X (2013). What drives stock price movements? Review of Financial Studies, 26(4), 841-876. https://doi. org/10.1093/rfs/hht005

10. Chinzara, Z. (2011).

Macroeconomic uncertainty and conditional stock market volatility in South Africa. South African Journal of Economics, 79(1), 27-49. https://doi.org/10.1111/j.18136982.2011.01262.x

11. Dornbusch, R., \& Fischer, S. (1986). The Open Economy: Implications for Monetary and Fiscal Policy. In The American Business Cycle: Continuity and Change. Chicago: University of Chicago Press.

12. Ewing, B. T., \& Thompson, M. A. (2007). Worker compensation and macroeconomic shocks in serviceand goods-producing sectors. International Journal of Services and Operations Management, 3(4). https://doi.org/10.1504/IJSOM.2007.013463

13. Fama, E. F. (1970). Efficient Capital Markets: A Review of Theory and Empirical Work. The Journal of Finance, 25(2), 383-417. https://doi.org/10.2307/2325486

14. Fama, E. F., \& French, K. R. (1989). Business conditions and expected returns on stocks and bonds. Journal of Financial Economics, 25(1), 23-49. https://doi.org/10.1016/0304405X(89)90095-0

15. Garefalakis, A. E., Dimitras, A., Koemtzopoulos, D., \& Spinthiropoulos, K. (2011). Determinant factors of Hong Kong stock market. International Research Journal of Finance and Economics, 62, 50-60. https://doi. org/10.2139/ssrn.1762162 
16. Garg, K., \& Kalra, R. (2018). Impact of Macroeconomic Factors on Indian Stock Market. Parikalpana: KIIT Journal of Management, 14(1), 134-145. https://doi.org/10.23862/kiit-parikalpana/2018/v14/i1/173248

17. Horobet, A., \& Dumitrescu, S. (2009). On the causal relationships between monetary, financial and real macroeconomic variables: Evidence from central and Eastern Europe. Economic Computation and Economic Cybernetics Studies and Research. Retrieved from http://www.ecocyb.ase.ro/articles\%203.2009/Alexandra\%20 Horobat.pdf

18. Hsing, Y., \& Hsieh, W.-J. (2012) Impacts of macroeconomic variables on the stock market index in Poland: New evidence. Journal of Business Economics and Management, 13(2), 334-343. https://doi.org/10.3846/16111699. 2011.620133

19. Hsing, Y., Zee, S. M. L., Budden, M. C., \& Cope, R. F. (2012). Impacts of the aggregate economic and financial conditions on output in an emerging economy. Journal of Applied Business Research, 28(2), 261-268. https://doi.org/10.19030/ jabr.v28i2.6847

20. Jensen, G. R., \& Johnson, R. R. (1995). Discount rate changes and security returns in the U.S., 1962-1991. Journal of Banking and Finance, 19(1), 79-95. https://doi. org/10.1016/0378-4266(94)000488

21. Keynes, J. M. (1937). The general theory of employment. Quarterly Journal of Economics, 51(2), 209-223. https://doi. org/10.2307/1882087

22. Khan, J., \& Khan, I. (2018). The Impact of Macroeconomic Variables on Stock Prices: A Case Study of Karachi Stock Exchange. Journal of Economics and Sustainable Development, 9(13), 15-25. Retrieved from https://core. ac.uk/download/pdf/234648422. pdf

23. King, R. G., \& Watson, M. W. (1996). Money, prices, interest rates and the business cycle. Review of Economics and
Statistics, 78(1), 35-53. https://doi. org/10.2307/2109846

24. Kurov, A., \& Gu, C. (2016). Monetary Policy and Stock Prices: Does the "Fed Put" Work When It Is Most Needed? Journal of Futures Markets, 36(12), 12101230. https://doi.org/10.1002/ fut. 21790

25. Le, Q. M. (2010). Application of Markowitz Model in explaining the attractiveness of bank stock. Journal of Banking Technology (Vietnam), 54, 39-44.

26. Luthra, M., \& Mahajan, S. (2014). Impact of Macro factors on BSE Bankex. International Journal of Current Research and Academic Review, 2(2), 179-186. Retrieved from https://citeseerx.ist.psu.edu/ viewdoc/download?doi=10.1.1.42 $8.9816 \&$ rep $=$ rep $1 \&$ type $=$ pdf

27. Miller, M. H., \& Modigliani, F. (1961). Dividend Policy, Growth, and the Valuation of Shares. The Journal of Business, 34(4), 411-433. https://doi.org/10.1086/294442

28. Mishra, A. K., Rath, B. N., \& Dash, A. K. (2020). Does the Indian Financial Market Nosedive because of the COVID-19 Outbreak, in Comparison to after Demonetisation and the GST? Emerging Markets Finance and Trade, 56(10), 2162-2180. https://doi.org/10.1080/154049 6X.2020.1785425

29. Miskin, F. S. (2001). The transmission mechanism and the role of asset prices in monetary policy (NBER Working Paper No. 8617). National Bureau of Economic Research. Retrieved from https://www.nber.org/system/files/working_papers/w8617/ w8617.pdf

30. Montes, G. C., \& Tiberto, B P. (2012). Macroeconomic environment, country risk and stock market performance: Evidence for Brazil. Economic Modelling, 29(5), 1666-1678. https://doi.org/10.1016/j.econ$\bmod .2012 .05 .027$

31. Moore, T., \& Wang, P. (2014). Dynamic linkage between real exchange rates and stock prices: Evidence from developed and emerging Asian markets. International Review of Economics and Finance, 29, 1-11. https://doi. org/10.1016/j.iref.2013.02.004

32. Narayan, P. K., \& Bannigidadmath, D. (2015). Are Indian stock returns predictable? Journal of Banking \& Finance, 58, 506-531. https://doi.org/10.1016/j.jbankfin.2015.05.001

33. Narayan, P. K., Sharma, S. S., \& Thuraisamy, K. S. (2015). Can governance quality predict stock market returns? New global evidence. Pacific-Basin Finance Journal, 35(A), 367-380. https://doi.org/10.1016/j.pacfin.2015.02.007

34. Naveed, M. Y., \& Ramzan, P. D. M. (2013). A View About the Determinants of Change in Share Prices: a Case From Karachi Stock Exchange (Banking Sector). Interdisciplinary Journal of Contemporary Research in Business, 4(12), 41-57. Retrieved from https://journal-archieves31.webs. com/41-57.pdf

35. Nguyen, T. H. (2017). Banking stock returns in Vietnam: the effects of macroeconomic fluctuations and recommended policies. Journal of Banking Technologies (Vietnam), 136, 44-54.

36. Osamwonyi, I. O., \& EvbayiroOsagie, E. I. (2012). The Relationship between Macroeconomic Variables and Stock Market Index in Nigeria. Journal of Economics, 3(1), 55-63. https://doi.org/10.1080/09765239. 2012.11884953

37. Phan, D. H. B., Sharma, S. S., \& Narayan, P. K. (2015). Stock return forecasting: Some new evidence. International Review of Financial Analysis, 40, 38-51. https://doi. org/10.1016/j.irfa.2015.05.002

38. Ross, S. A. (1976). The arbitrage theory of capital asset pricing. Journal of Economic Theory, 13(3), 341-360. https://doi. org/10.1016/0022-0531(76)900466

39. Sharpe, W. F. (1964). Capital Asset Prices: A Theory of Market Equilibrium Under Conditions of Risk. The Journal of Finance, 
19(3), 425-442. https://doi. org/10.1111/j.1540-6261.1964 tb02865.x

40. Shula, K. (2017). The Impact of GDP, Inflation, Interest and Exchange rates GDP on the Stock Market in Zambia (EAZ Working Paper No. 2). https://doi. org/10.13140/RG.2.2.11457.56160

41. Singhal, S., Choudhary, S., \& Biswal, P. C. (2019). Return and volatility linkages among International crude oil price, gold price, exchange rate and stock markets: Evidence from Mexico. Resources Policy, 60(1), 255-269. https://doi.org/10.1016/j.resourpol.2019.01.004

42. Stulz, R. M. (1999). Golbalization, Corporate Finance, and the Cost of Capital. Journal of Applied Corporate Finance,
12(3), 8-25. https://doi. org/10.1111/j.1745-6622.1999. tb00027.x

43. Ton, T. T. (2007). Why are bank stock prices falling down? Journal of Banking (Vietnam), 13, 29-33.

44. Vo, X. V. (2015). Operating efficiency and bank stock returns in Vietnam. Journal of Banking Technology (Vietnam), 109, 34-42. 